\title{
NATIONAL CULTURE IMPACT ON LEAN LEADERSHIP AND LEAN MANUFACTURING MATURITY - CASE STUDY OF MULTINATIONALS BASED IN MOROCCO
}

\author{
Youssef Larteb $^{1}$, Abdellah Haddout ${ }^{2}$, Mariam Benhadou ${ }^{3}$ \\ ${ }^{1}$ PHD Student, Team rheology and industrial plastics processing, ENSEM, Casablanca, Morocco \\ ${ }^{2}$ Professor, Team rheology and industrial plastics processing, ENSEM, Casablanca, Morocco \\ ${ }^{3}$ Professor, Team rheology and industrial plastics processing, ENSEM, Casablanca, Morocco
}

\begin{abstract}
A large body of researches has demonstrated that cultural values directly influence the success of organizational strategies and managerial actions. On the same way, the successful use of Lean Manufacturing (LM) practices requires more than the use of tools. Although many manufacturing facilities worldwide use LM practices, dimensions of nation's culture and leadership may moderate the expected results from the LM implementation. Using LM background and cultural data, this paper presents the results of an exploratory study on the moderation of Lean Leadership effectiveness by dimensions of national cultural values. The study was based on the feedback from the practice of Lean Leadership in various multinationals based in Morocco. A questionnaire was elaborated, validated, and sent to overall 120 respondents holding various management and operational positions in many multinational companies. The results of this study are used to identify directions for proposing an adapting model of operations management to the Moroccan SMEs.
\end{abstract}

Keywords: Survey, Lean Manufacturing, Lean Leadership, National culture, Organizational culture, Multinational, Morocco.

\section{INTRODUCTION}

LM is more a philosophy than just a toolbox; it is a fully integrated management and manufacturing philosophy and approach [2]. However, it also made clear, that the tools are important, but the basic tenet of LM is that lean culture and Lean Leadership are the most important factors. Additionally, the strong balance among technological efficiency and leadership effectiveness has been largely considered as the limit that separates success and failure of LM implementation projects [22], [40], [38], [11], [17], [8], [44]. Taking into account that cost pressure seems to force organizations to relocate work into low cost countries, like Morocco, an investigation of LM perceptions, risk factors on the lean pathway proves very important. In absence of studies and research in Morocco related to LM, there is no clear evidence of the level of success and problems/barriers in the LM implementation in those organizations. Some problems/ barriers that might cause company to stumble may root of the leadership of management [36] and the specific national culture who can indirectly influences leadership behaviors differently to LM requirements [19]. Because the national cultures are quite diverse, and the ways of practicing leadership seem to be subject to the influence of the social and cultural environment in which they are used, the resulting organizations and the work systems are equally diverse [41].
Thus, the purpose of this study is to explore the status of Lean Leadership maturity in multinational facilities based in Morocco. Especially, the status aims to discover the perception of managers toward the LM in terms of understanding of the concepts, the assumption of Lean Leadership roles, and to confirm the hypothesis of a role of national culture in nurturing the lean culture and its influence on the Lean Leadership maturity.

The following section reviews the literature and related theory to LM, Lean Leadership, and the cultural impact. Next we describe the data, sample, and measures. We then discuss the results. Finally we point out the contributions to both the academic and more to the practitioner literature.

\section{LITERATURE REVIEW}

\subsection{Lean Manufacturing and Lean Leadership}

Lean Manufacturing (LM) is often regarded as the most important strategy for manufacturing firms desiring to achieve world-class performance [24]. LM is a collective term for production practices aimed at increasing value creation and reducing waste in all forms. LM refers to an integrated social-technical system whose main objective is to eliminate waste by concurrently reducing or minimizing supplier, customer, and internal variability [47]. Therefore, the main objective of LM is to achieve maximum efficiency, carrying out operations at a minimum cost and with zero waste [40]. 
However, any transfer of organization or management techniques is also a transfer of leadership profile and organizational culture [39]. Although manufacturing facilities worldwide use LM practices, dimensions of leadership and nation's culture my moderate LM results [33]. According to [35], LM programs fail because managers have confused lean solutions for the process that led to what we see in a Toyota factory and specific Lean Leadership that daily involved employees in these processes. [17] introduced the Lean Leadership as a methodical system for the sustainable implementation and continuous improvement of the LM. Lean Leadership is a continuous process that involves making followers want to contribute to continuous improvement and process excellence. This includes the customer orientation, proximity management, as the long-term development of employees. To be able to transform the entire organization into a lean organization, the Lean Leadership must be, assimilated, understood, and modeled across all management levels.

\subsection{Lean Manufacturing Practices, National and}

\section{Organizational Culture}

Managers are encouraged to implement LM practices globally because of its universal effectiveness. However, as a successful implementation of any continuous improvement demarche can only be achieved if the employees believe in the change that is about to happen, the implementation process of the LM needs to be adjusted to specific external and internal characteristics of each organization [3]. So, for the expected performance of the LM, several behavioral adjustments and managerial interventions may be necessary in each LM adoption. This implies that the form and use of such LM practices as waste reduction, $5 \mathrm{~S}$, and just-in-time, may be guided by the underlying cultural values of managers and workers in a facility [48].

Given that countries vary in their cultural values [30], incongruence between national culture and lean culture may corrupt the practice of LM and moderate expected performance improvements [33]. In his research on the moderation of LM effectiveness by dimensions of national culture, and by analyzing data from more than 1400 facilities in 24 countries, [33] confirms that LM is more effective in a future-oriented (FO), performance-oriented (PO), and assertive national culture (AS). Likewise, [25], in his analyze of the cultural lean inhibitor impact breakdown, suggests that the cultural barriers affect all the five aspects of LM (The Value, Value stream, Continuous Flow, Customer Pull, and Perfection). Therefore, when there is no tension between national and lean culture, LM practices are easier to implement and hence will have higher performance. In contrast, divergence between national and lean culture could make implementing LM problematic.

Nevertheless, in the GLOBE study about leadership effectiveness and culture, [19] argue that national culture does NOT predict leadership behavior or organizational culture included lean culture. Too, [44], in his study of 189 manufacturing plants between Eastern (Japan and south Korea) and Western (Germany, United States, Finland, and Sweden) countries, indicates that organizational culture has more an effect on manufacturing performance than national culture, and in result, a weak influence of national level factors on manufacturing performance. Likewise, [7], in his research about the role of organizational culture in LM, sustains that a specific organization culture profile characterizes all successful lean plants; Thus plants, compared to unsuccessful lean plants, show an organizational culture marked by more institutional collectivism (IC), a strong future orientation (FO), and a big human orientation (HO). Yet, [4] and [41], argument that the "culture of work" matters more than national culture in the degree to which manufacturing practices can be applied across countries. In an era of globalization, these results have practical implications for national organizations and organizations expanding across national boundaries by developing an internal organizational culture consistent with LM requirements whatever the culture of the country of relocation

\section{RESEARCH AND DATA ANALYSIS}

\subsection{Sample Selection and Analysis Approach}

The empirical research took place end of 2014. The data was captured through meticulous survey questionnaires undertaken in various multinationals based in Morocco whose production processes related to automotive and aeronautic manufacturing. Although the companies targeted were international, staff will predominantly be Moroccan, enhancing our ability to identify national cultural influences on our findings. The survey questionnaire items were developed based on LM background, Lean Leadership fundamentals, and cultural data. The survey questionnaire was split into the following categories with several or more questions in each category to determine:

- the perception about the LM,

- the critical practices of Lean Leadership,

- behavioral effects of Lean Leadership on the shop floor,

\subsection{Data Analysis \& Results}

Table -1: Sample characteristics

\begin{tabular}{|l|l|l|}
\hline $\begin{array}{l}\text { Industrial } \\
\text { sectors in sample }\end{array}$ & Subdivision & \% of total \\
\hline \multirow{4}{*}{$\begin{array}{l}\text { Multinational } \\
\text { origin }\end{array}$} & French & 50 \\
\cline { 2 - 3 } & Japan & 25 \\
\cline { 2 - 3 } & Germany & 17 \\
\cline { 2 - 3 } & USA & 8 \\
\hline Industry sector & Automotive & 50 \\
\cline { 2 - 3 } & Aeronautic & 42 \\
\cline { 2 - 3 } & Others & 8 \\
\hline \multirow{5}{*}{ Function } & Corporate & 16 \\
\cline { 2 - 3 } & Methods \& Process & 32 \\
\cline { 2 - 3 } & Quality & 22 \\
\cline { 2 - 3 } & Production & 25 \\
\hline
\end{tabular}




\begin{tabular}{|l|l|l|}
\hline & Logistics & 6 \\
\hline \multirow{3}{*}{$\begin{array}{l}\text { Hierarchical } \\
\text { level }\end{array}$} & $\begin{array}{l}\text { Director } \\
\text { Superintendent }\end{array}$ & 16 \\
\cline { 2 - 3 } & Manager & 53 \\
\cline { 2 - 3 } & Supervisor & 31 \\
\hline
\end{tabular}

In total, 41 questionnaires have been returned, of which two had to be discarded because of insufficient data, yielding 39 usable questionnaires (34\% response rate). Table.1 provides an overview of the responses by sector, by multinational origin, by function, and by hierarchical level of respondents. The majority of the respondents to the survey were managers (53\%) and supervisors (31\%). Two hierarchical positions enhancing our ability to identify critical Lean Leadership behaviors. Finally, 50\% of factories are French, 25\% Japanese, $17 \%$ German, and 8\% American.

Table - 2: Questionnaires responses regards the lean perception

\begin{tabular}{|l|l|}
\hline Lean perceptions & $\%$ \\
\hline Away to create new work and business & 17.39 \\
\hline A fully integrated management philosophy & 21.74 \\
\hline $\begin{array}{l}\text { A philosophy that absolutely focuses on } \\
\text { customer value (customer first focus) }\end{array}$ & 21.74 \\
\hline $\begin{array}{l}\text { A system for organizing and managing } \\
\text { product development, operations, } \\
\text { suppliers, and customer relations }\end{array}$ & 26.09 \\
\hline A method to reduce headcount & 39.13 \\
\hline $\begin{array}{l}\text { A system to make products with fewer } \\
\text { defects in order to strive for perfection }\end{array}$ & 39.13 \\
\hline $\begin{array}{l}\text { A system to reorganize the firm by product } \\
\text { family and value stream }\end{array}$ & 47.83 \\
\hline $\begin{array}{l}\text { The use of teamwork and continuous } \\
\text { improvement }\end{array}$ & 52.17 \\
\hline $\begin{array}{l}\text { A toolbox of techniques (just-in time \&. } \\
\text { automation) to improve manufacturing and } \\
\text { operations }\end{array}$ & 60.87 \\
\hline $\begin{array}{l}\text { The consequent elimination of non value } \\
\text { adding tasks in order to reduce lead time }\end{array}$ & 78.26 \\
\hline
\end{tabular}

First we analyzed the LM perception as a result of the understanding of LM philosophy using descriptive statistic. The questions were created on basis of various literature studies [50], [34], [22], [43], [30], [2], [45], [32]. Table.2 shows respondent views about LM perception. Unfortunately, an important conclusion was the reduction of lean concepts in a toolbox to reduce lead time $(78.26 \%)$ and improve operations $(60.87 \%)$, not in a fully integrated management and manufacturing philosophy (21.74\%) focused on customer satisfaction (21.74\%) trough the organization and management of product development, operations, suppliers and customer relations (26.09\%). Another interesting aspect is that only $17.39 \%$ seed the LM as a way to create new work and business; a significantly lower result than founded among our European neighbors evaluated at $42 \%$ [2]. As previously outlined, looking at the fact that through reducing the ultimate goal of lean to reducing the lead time it has to be said that quit a remarkable managers does not yet fully see the chances and potential of LM implementation [3]. Thus, unless managers in the company ignore about the potential of LM, improvement initiatives are less likely to be initiated and the miraculous gains in performance through LM are less likely to be reached.

Next, as mentioned earlier, we tried to understand, and predict the impact of specific national cultural values on Lean Leadership and LM practices and the effectiveness of these practices. Eight questions were formulated on the basis of the Lean Leadership literature review [50], [34], [35], [45], [16], [17], [40], [11], [38] to investigate about the critical Lean leadership practices in national culture and leadership values context. The results are summarized in Table.3.

Table - 3: Questionnaires responses regards the critical lean leadership practices in national culture and leadership values

\begin{tabular}{|c|c|c|c|c|}
\hline \multirow[b]{2}{*}{$\begin{array}{ll}\text { Lean } & \text { Leadership } \\
\text { fundamentals } & \end{array}$} & \multirow{2}{*}{$\begin{array}{l}\text { Difficul } \\
\text { ty } \\
\text { average }\end{array}$} & \multicolumn{3}{|c|}{ Difficulty scale (\%) } \\
\hline & & 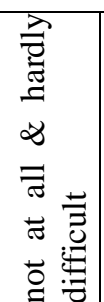 & 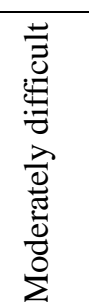 & 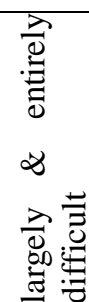 \\
\hline $\begin{array}{l}\text { Managers and production } \\
\text { supervisors motivate, } \\
\text { supervise, train and } \\
\text { facilitate the work to } \\
\text { operators rather than } \\
\text { telling them what to do }\end{array}$ & 57.49 & 4,35 & $\begin{array}{l}60,8 \\
7\end{array}$ & $\underline{34}$ \\
\hline $\begin{array}{l}\text { Managers and production } \\
\text { supervisors encourage and } \\
\text { actively participate with } \\
\text { employees in process } \\
\text { improvement projects and } \\
\text { performance indicators }\end{array}$ & 55.56 & $\underline{8,70}$ & $\begin{array}{l}56,5 \\
2\end{array}$ & $\underline{34,7}$ \\
\hline $\begin{array}{l}\text { Managers and supervisors } \\
\text { encourage operators to } \\
\text { participate in the problem- } \\
\text { solving process }\end{array}$ & 53.62 & 8,70 & $\begin{array}{l}65,2 \\
2\end{array}$ & $\begin{array}{l}26,0 \\
9\end{array}$ \\
\hline $\begin{array}{l}\text { For managers and } \\
\text { production supervisors, } \\
\text { quality goes ahead in } \\
\text { productivity } \\
\text { efficiency }\end{array}$ & 52.66 & $\begin{array}{l}13,0 \\
4\end{array}$ & $\begin{array}{l}56,5 \\
2\end{array}$ & $\underline{30,4}$ \\
\hline $\begin{array}{l}\text { Managers and production } \\
\text { supervisors actively } \\
\text { communicate with the } \\
\text { shop floor and animate } \\
\text { around objectives and } \\
\text { goals at regular time }\end{array}$ & 51.69 & $\underline{4,35}$ & $\begin{array}{l}65,2 \\
2\end{array}$ & $\underline{30,4}$ \\
\hline $\begin{array}{l}\text { Managers and production } \\
\text { supervisors communicate }\end{array}$ & 50.72 & 8,70 & $\begin{array}{l}73,9 \\
1\end{array}$ & $\begin{array}{l}17,3 \\
9\end{array}$ \\
\hline
\end{tabular}




\begin{tabular}{|c|c|c|c|c|}
\hline $\begin{array}{l}\text { strongly to the shop floor } \\
\text { about quality results }\end{array}$ & & & & \\
\hline $\begin{array}{l}\text { Managers and production } \\
\text { supervisors } \\
\text { responsible for product } \\
\text { quality }\end{array}$ & 47.83 & $\begin{array}{l}21,7 \\
4\end{array}$ & $\begin{array}{l}56,5 \\
2\end{array}$ & $\begin{array}{l}21,7 \\
4\end{array}$ \\
\hline $\begin{array}{l}\text { In quality problem case, } \\
\text { managers and production } \\
\text { supervisors encourage } \\
\text { operators to stop machines } \\
\text { and production lines - } \\
\text { Power stop the line } \\
\text { (Andon) }\end{array}$ & 47.83 & $\begin{array}{l}17,3 \\
9\end{array}$ & $\begin{array}{l}60,8 \\
7\end{array}$ & $\begin{array}{l}21,7 \\
4\end{array}$ \\
\hline
\end{tabular}

The findings about difficulty average number indicate that managers moderately assumed the quality of product, and moderately encouraged the shop floor employees to stop the line in any case of quality deviation with the same difficulty average number $(47.83 \%)$. Thus result provides other finding about the large difficulty for supervisors to put quality above productivity and efficiency (52.66\%). Also, the results indicate that managers and supervisors are less performing in motivating and supervising, training, and facilitating the work in the shop floor with a difficulty average number of $57.49 \%$. This study indicates also an average difficulty of $55.56 \%$ for managers and supervisors to encourage and participate with employees in both process and performance indicators improvement projects. Unfortunately, research among successful organizations indicates that results are better if performance managements is focused on supporting improvement rather than just for monitoring and control the shop floor. Changes in the role and behavior of top and middle management by less information flow stagnation, transparency, direct contact with the shop floor, and continuous management support to workers are considered the cornerstone of successful LM implementation. Likewise, as [22] note, management practices, such as employee involvement in continuous improvement programs, employee integration in problemsolving teams, and employee training, are acknowledged to form core components of a LM program. Such as Lean Leadership literature advocates that management should function as a facilitator rather than supervisor [44], managers have to support the continuous improvement culture by living it and setting an example [17].

In the last, we analyzed the influence of Lean Leadership practices on the shop floor behavior. The results are presented in Table.4, which show, for each lean requirement in the shop floor employee behavior the average number of difficulty.
Table- 4: Questionnaires responses regards the behavioral effects of the Lean Leadership practices on the shop floor

\begin{tabular}{|c|c|c|c|c|}
\hline $\begin{array}{l}\text { Difficulty } \\
\text { average }\end{array}$ & & Diffic & ty scal & $\%)$ \\
\hline $\begin{array}{l}\text { Lean requirements in } \\
\text { the shop floor } \\
\text { employee behavior }\end{array}$ & $\%$ & 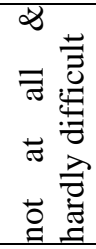 & 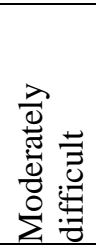 & 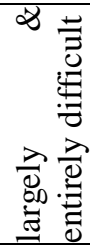 \\
\hline $\begin{array}{l}\text { In case of quality } \\
\text { problem, operators } \\
\text { insist to stop lines and } \\
\text { production machinery } \\
\text { (Andon system) }\end{array}$ & 52.66 & 13.04 & 60.87 & 26.09 \\
\hline $\begin{array}{l}\text { Operators are actively } \\
\text { involved in both } \\
\text { standards and processes } \\
\text { improvement projects }\end{array}$ & 50.72 & 8.70 & 78.26 & 13.04 \\
\hline $\begin{array}{l}\text { Operators maintain and } \\
\text { respect workplace } \\
\text { standards and warn of } \\
\text { any damage or } \\
\text { deviation }\end{array}$ & 50.72 & 13.04 & $\underline{69.57}$ & 17.39 \\
\hline $\begin{array}{l}\text { Operators participate } \\
\text { and are actively } \\
\text { involved in problem- } \\
\text { solving process }\end{array}$ & 48.79 & 8.70 & 82.61 & 8.70 \\
\hline $\begin{array}{l}\text { Operators respect } \\
\text { instructions and quality } \\
\text { specifications }\end{array}$ & 42.03 & 17.39 & 73.91 & 8.70 \\
\hline
\end{tabular}

Decidedly, it can be observed that behavioral on the shop floor are largely influenced by specific Lean Leadership practices. The findings about difficulty average number indicate that the shop floor operators are moderately less focusing on improvement $(50.72 \%)$ and problem solving $(48.79 \%)$. Equally, the results revealed that the shop floor operators are moderately less inciting to stop lines in case of quality problem $(52.66 \%)$. These results can be considered a revealing consequence of large difficulty for managers to put quality above productivity and efficiency (52.66\%) depicted in Table.3. The finding is totally agreed with operations management researches also believe that Lean Leadership has implications for employee outcomes [27]. Likewise, these results provide various researches examining the link between management behavior and LM performance and clearly assume that leadership affect behavior of individuals in the shop floor, which in a positive case facilitates the achievement of LM promises regarding organizational benefits and customer satisfaction. Consequently, it is the integration of LM practices in the shop floor through a perfect Lean Leadership that would have the ability to achieve multiple organizational goals and superior result in quality of product and service [12]. 


\section{CONCLUSION}

The objective of this study was to close a gap in Lean Manufacturing research in Morocco by analyzing the moderation of Lean Leadership effectiveness by dimensions of national cultural by exploring the status of Lean Leadership practices in various multinationals located in the country. To summarize it can be concluded that the survey findings fit with existing theory. As shown in Table.3, managers and supervisors are less focused in continuous improvement projects and less performing in training the shop floor employees. These results provide a deeper understanding of why major organizations find implementing and using Lean Manufacturing practices difficult. The explanation for this finding is that Lean Manufacturing and quality approaches require a fundamentally different philosophy of management than the traditional mass production approach.

Next, we have investigated the relation between Lean Leadership practices and each of these behavioral effects, as depicted in Table.4. This table confirms the broad impact of leadership on the shop floor behavior. It is also a further confirmation of various researches who argued that the success of Lean Manufacturing depends heavily on the topmost leaders embracing it, believing in it, and properly applying it. Consequently, no lean behaviors will be sustained unless they are modeled. Thus, managers must model the lean behavior they desire if they expect it from their shop floor employees.

\section{REFERENCES}

[1]. Acosta, C., Jorge Leon, V., Conrad, C., Gonzalez, R., Malave, O.C., 2004. Case study on culture and the implementation of Manufacturing Strategy in Mexico. Journal of Manfucaturing Systems 23 (3) 204-214.

[2]. Ahrens, T., 2006. Lean production: Successful implementation of organizational change in operations instead of short term cost reduction efforts. Lean Alliance, $1-87$

[3]. Bakas, O., 2011. Challenges and success factors for implementation of Lean Manufacturing in European SMES. Norwegian University of Science and Technology, Trondheim, Norway, MITIP.

[4]. Barmeyer, C., Mayrhofer, U., 2008. The contribution of intercultural management to the success of international mergers and acquisitions: An analysis of the EADS group. International Business Review 17, 28-38.

[5]. Bhasin, S., 2012. Performance of Lean in large organizations. Journal of Manfucaturing Systems 31, 349357

[6]. Bloom, N., Reenen, V.J., 2010. Why do management practices differ across firms and countries? The journal of economic perspectives 24 (1) 203-224.

[7]. Bortolotti, T., Boscari, S., Danese, P., 2014. Successful lean implementation: Organizational culture and soft lean practices. International Journal of Production Economics, http://dx.doi.org/10.1016/j.ijpe.2014.10.013i

[8]. Chattergoon, S., Darling, S., Devitt, R., Klassen, W., 2014. Creating and sustaining value: Building a culture of continuous improvement. Healthcare Management Forum 27, 5-9.

[9]. Cuatrecasas, A.L., 2002. Design of a rapid response and high efficiency service by lean production principles: Methodology and evaluation of variability of performance. Int.J. Production Economics 80, 169-183.

[10]. De hann, J., Naus, F., Overboom, M., 2012. Creative tension in a lean work environment: Implications for logistic firms and workers. Int.J. Production Economics 137, 157164.

[11]. De Leeuw, S., Van den Berg, P.J., 2011. Improving operational performance by influencing shopfloor behavior via performance management practices. Journal of Operations Management 29, 224-235.

[12]. De Menezes, M.L, Wood, S., Gelade, G., 2010. The integration of human resource and operation management practices and its link with performance: A longitudinal latent class study. Journal of operations Management 28, 455-471.

[13]. Demeter, K., 2014. Operating internationally - The impact on operational performance improvement. Int.J. Production Economics 149, 172-182.

[14]. De Treville, S., Antonakis, J., 2006. Could lean production job design be intrinsically motivating? Contextual, configurational, and levels-of-analysis issues. Journal of Operations Management 24, 99-123

[15]. Doeringer, P., Evans-Klock, C., Terkla, D., 2002. What attracts high performance factories? Management culture and regional advantage. Regional Science and Urban Economics 34, 591-618

[16]. Dombrowski, U., Mielke, T., 2013. Lean Leadership fundamental principles and their application. Procedia CIRP 7, $569-574$

[17]. Dombrowski, U., Mielke, T., 2014. Lean Leadership 15 Rules for a sustainable Lean Implementation. Procedia CIRP 17, $565-570$

[18]. Doolen, L.T, Hacker, E.M., 2005. A Review of Lean Assessment in Organizations: An Exploratory Study of Lean Practices by Electronics Manufacturers. Journal of Manufacturing system 24 (1)

[19]. Dorfman, P., Javidan, M., Hanges, P., Dastmalchian, A., House, R., 2012. GLOBE: A twenty year journey into the intriguing world of culture and leadership. Journal of World Business 47, 504-518

[20]. Duque, M.F.D., Cadavid, R.L., 2007. Lean manufacturing measurement: The relationship between lean activities and lean metrics. Estudios Gerenciales 23 (105) 69-83

[21]. Evans, R.J., Lindsay, R.J., 2005. The Management and Control of Quality. 6th edition South-Western College Publication, Cincinnati, $\mathrm{OH}$.

[22]. Farris, A.J., Van Aken, M.E., Doolen, L.T., Worley, J., 2009. Critical success factors for human resource outcomes in Kaizen events: An empirical study. Int. J. Production Economics 117, 42-65.

[23]. Forster, G., Fenwick, J., 2014. The influence of Islamic values on management practice in Morocco. European Management Journal 10.1016/j.emj.2014.04.002.

[24]. Fullerton, R.R, Kennedy, F.A., Widener, S.K., 2013. Management accounting and control practices in a lean 
manufacturing environment. Accounting, Organizations and Society 38, 50-71.

[25]. Garza, A.L., 2005. Integrating Lean Principals in Automotive Product Development: Breaking Down Barriers in Culture and Process. Master's thesis at the Massachusetts Institute of Technology.

[26]. Halkos, G.E., Tzeremes, N.G., 2011. Modelling the effect of national culture on multinational bank's performance: A conditional robust nonparametric frontier analysis $28,515-525$

[27]. Handel, J.M., 2014. Theories of lean management: An empirical evaluation. Social science research 44, 86-102

[28]. Hicks, J.B., 2007. Lean information management: Understanding and eliminating waste. Int. J. Information Management 27, 233-249

[29]. Holtskog, H., 2013. Continuous Improvement beyond the Lean understanding. Procedia CIRP 7, 575 -579

[30]. House, R., Javidan, M., Hanges, P., Dorfman, P., 2002. Understanding cultures and implicit leadership theories across the globe: an introduction to project GLOBE. Journal of World Business 37, 3-10.

[31]. Jayaram, J., Das, A., Nicolae, M., 2010. Looking beyond the obvious: Unraveling the Toyota production system. Int. J. Production Economics 128, 280-291.

[32]. Kull, J.T., Wacker, G.J., 2010. Quality management effectiveness in Asia: The influence of culture. Journal of Operations Management 28, 233-239.

[33]. Kull, J.T., Yan, T., Liu, Z., Wacker, G.J., 2014. The moderation of Lean manufacturing effectiveness by dimensions of national culture: Testing practice-culture congruence hypotheses. Int. J. Production Economics 153, $1-12$.

[34]. Liker, J., 2004. Le modèle Toyota : 14 principes qui feront la réussite de votre entreprise. Pearson France, Paris.

[35]. Liker, J., Ogden, T., 2011. Toyota, un modèle de gestion de crise. Pearson Education France, Paris.

[36]. Lila, B., 2012. A survey on implementation of the Lean Manufacturing in Automotive Manufacturers in the Eastern Region of Thailand. International Conference on industrial Technology and Management 49, 43-49

[37]. Lindeke, R.R., Wyrick, A.D., Chen, H., 2009. Creating change and driving innovation in highly automated and lean organization: The Temporal Think Tank (T3). Robotics and Cumputer-Integrated Manufacturing 25, 879-887.

[38]. Losonci, D., Demeter, K., Jenei, I., 2011. Factors influencing employee perceptions in lean transformations. Int. J. Production Economics 131, 30-43.

[39]. Lyonnet, B., 2010. Amélioration de la performance industrielle - vers un système de production Lean adapté aux entreprises du pôle de compétitivité Arve Industries Haute-Savoie Mont-Blanc. Mémoire de thèse doctorat. [40]. Martinez-Jurado, J.P., Moyano-Fuentesa, J., JerezGômezb, P., 2014. Human resource management in Lean Production adoption and implementation processes: Success factors in the aeronautics industry. BRQ Business Research Quarterly 17, 47-68.

[41]. Matten, D., Geppert, M., 2004. Work systems in heavy engineering: The role of national culture and national institutions in multinationals corporations. Journal of International Management 10, 177-198.
[42]. Miller, M. Lean Culture and Leadership Factors. A Survey of Lean Implementers' Perceptions of Execution and Importance. www.ManagementMeditations.com, p.1-17. [43]. Pamfilie, R., Petcu, J.A., Graghici, M., 2012. The importance of leadership in driving a strategic Lean Six Sigma management. Procedia - Social and Behavioral Sciences 58, 187-196.

[44]. Naor, M., Linderman, K., Schroeder, R., 2010. The globalization of operations in Eastern and Western countries: Unpacking the relationship between national and organizational culture and its impact on manufacturing performance. Journal of Operations Management 28, 194205.

[45]. Naor, M., Jones, S.J., Bernardes,S.E., Goldstein, M.S., Schroeder, R., 2014. The culture-effectiveness link in performance in a manufacturing context: A resource-based perspective. Journal of World Business 49, 321-331.

[46]. Shah, R., Ward, T.P., 2003. Lean manufacturing: context, practice bundles, and performance. Journal of Operations Management 21, 129-149

[47]. Shah, R., Ward, T.P., 2007. Defining and developing measures of lean production. Journal of Operations Management 25, 785-805

[48]. Schroeder, G.R, Flynn, B.B., 2001. High Performance Manufacturing : Global Perspectives. Wiley, New York.

[49]. Spear, S., Bowen, K.H., 1999. Decoding the DNA of the Toyota production system. Harvard Business Review 77 (5) 96-106

[50]. Womack.J and Jones.D. Le système Lean : Penser à l'entreprise au plus juste. Pearson France, Paris.

[51]. Zu.X, Robbins.L.T, Fredendall.D.L. Mapping the critical links between organizational culture and TQM/Six Sigma practices. Int. J. Production Economics 123 (2010) 86-106. 